\title{
Clinical-Scientific Note:
}

\section{Smoke but no fire: increased myocardial infarction with normal coronary arteries in the Australian bushfires?}

\begin{abstract}
Amanda Sherwen Cardiology Registrar MBBS, Elizabeth Paratz Cardiologist MBBS(Hons) FRACP, A/Prof Andre La Gerche Cardiologist MBBS PhD FRACP FCSANZ, A/Prof David Prior Cardiologist MBBS PhD FRACP FCSANZ, A/Prof Andrew Maclsaac Cardiologist MBBS MD FRACP FCSANZ
\end{abstract}

\author{
Corresponding Author: \\ Dr Elizabeth Paratz \\ Cardiologist, St Vincent's Hospital Melbourne \\ 41 Victoria Parade Fitzroy VIC 3065 \\ eparatz@hotmail.com
}

Word Count: 495 words

Figures: 1

Keywords: bushfire; environmental medicine; cardiology; acute coronary syndrome The recent Australian bushfires of December/January 2020 led to declaration of a state of emergency in multiple states. Concerns have previously been raised that smoke exposure may trigger increased rates of acute coronary syndrome and cardiac arrest (1-3). It is important to collate recent experiences to support ongoing investigations in this area.

This is the author manuscript accepted for publication and has undergone full peer review but has not been through the copyediting, typesetting, pagination and proofreading process, which may lead to differences between this version and the Version of Record. Please cite this article as doi: 10.1111/imj.15056

This article is protected by copyright. All rights reserved. 
Our hospital is a major tertiary receiving hospital for cardiology transfers from the Albury-Wodonga and East Gippsland regions, two areas most affected by the 2019/2020 bushfires. We performed an analysis of acute coronary syndrome (ACS) cases transferred from these regions between $29^{\text {th }}$ December 2019 to $10^{\text {th }}$ January 2020. This timeframe represented the height of the Victorian bushfires. Cases transferred from bushfire-affected regions in this time-period were compared to ACS cases transferred in the identical date range from the two years prior. At these control time points, the regions were not significantly affected by bushfire activity (median relative air quality index on patient transfer days 134 in 2020 versus 31 in 2019 and 22 in 2018, p<0.0001). Transfers from both bushfire-affected and non-bushfire affected regions were included in the control group, to assess whether any increased ACS volume was due to overall service expansion. We hypothesised that an increase in ACS cases might be observed, with elderly patients with multiple comorbidities predominantly affected.

We identified that 11 patients were transferred in 13 days from the bushfire-affected regions in 2020 , representing an increase of $24.6 \%$ in case volume from previous years, whereas case volume from non-bushfire affected Victoria remained stable (Figure 1, 11/19 patients in 2020 from bushfireaffected regions vs $9 / 27$ patients in 2018 and 2019 combined). No bushfire-affected patients were first responders to the fires or members of emergency services. All bushfire-affected patients had chest pain and elevated troponin level, with median troponin value 1,271ng/L (interquartile range $546-6,807 \mathrm{ng} / \mathrm{L}$, normal <16ng/L).

In comparison with the control group of ACS patients bushfire-affected patients were more commonly female $(5(45.5 \%)$ from bushfire areas vs $4(14.8 \%)$ in the control group, $p=0.044)$ and more likely to be diagnosed with myocardial infarction with non-obstructive coronary arteries (MINOCA) or Takotsubo cardiomyopathy (5 (45.5\%) vs $3(7.4 \%), p=0.045)$. There was no significant difference between the two groups with regards to median age, presence of smoking history, median number of cardiovascular risk factors, history of respiratory disease, median troponin level, or presence of ischaemic changes on electrocardiogram.

The numbers in this study represent early data from a recent catastrophic national experience. Media and researchers have proposed that the majority of cardiovascular morbidity from the bushfires would be borne by either firefighters with highest smoke exposure or the elderly (4). Our experience demonstrates that the greatest increase in case volume was in females (median age 62.4 years) experiencing either a MINOCA event or Takotsubo cardiomyopathy in the context of high levels of community stress.

Although the numbers are modest, our findings are unexpected and warrant further investigation. We believe that it is vital to create collaborative research examining the cardiovascular impact of bushfires, and strongly support further collaborative studies and longitudinal follow-up of affected patients. This will help guide improved healthcare planning and support during future bushfire events. 


\section{References}

1. Dennekamp M, Straney LD, Erbas B, Abramson MJ, Keywood M, Smith K, et al. Forest Fire Smoke Exposures and Out-of-Hospital Cardiac Arrests in Melbourne, Australia: A Case-Crossover Study. Environ Health Perspect. 2015;123(10):959-64.

2. Haikerwal A, Akram M, Del Monaco A, Smith K, Sim MR, Meyer M, et al. Impact of Fine Particulate Matter (PM2.5) Exposure During Wildfires on Cardiovascular Health Outcomes. J Am Heart Assoc. 2015;4(7).

3. Zhao B JF, Salimi F, Kurabayashi M, Negishi K. Short-term exposure to ambient fine particulate matter and out-of-hospital cardiac arrest: a nationwide case-crossover study in Japan. Lancet Planet Health. 2020;4:15-23.

4. Gorman A. Doctors warn people may die as public health impact from Australian fire pollution bites. The Guardian. 2020. 

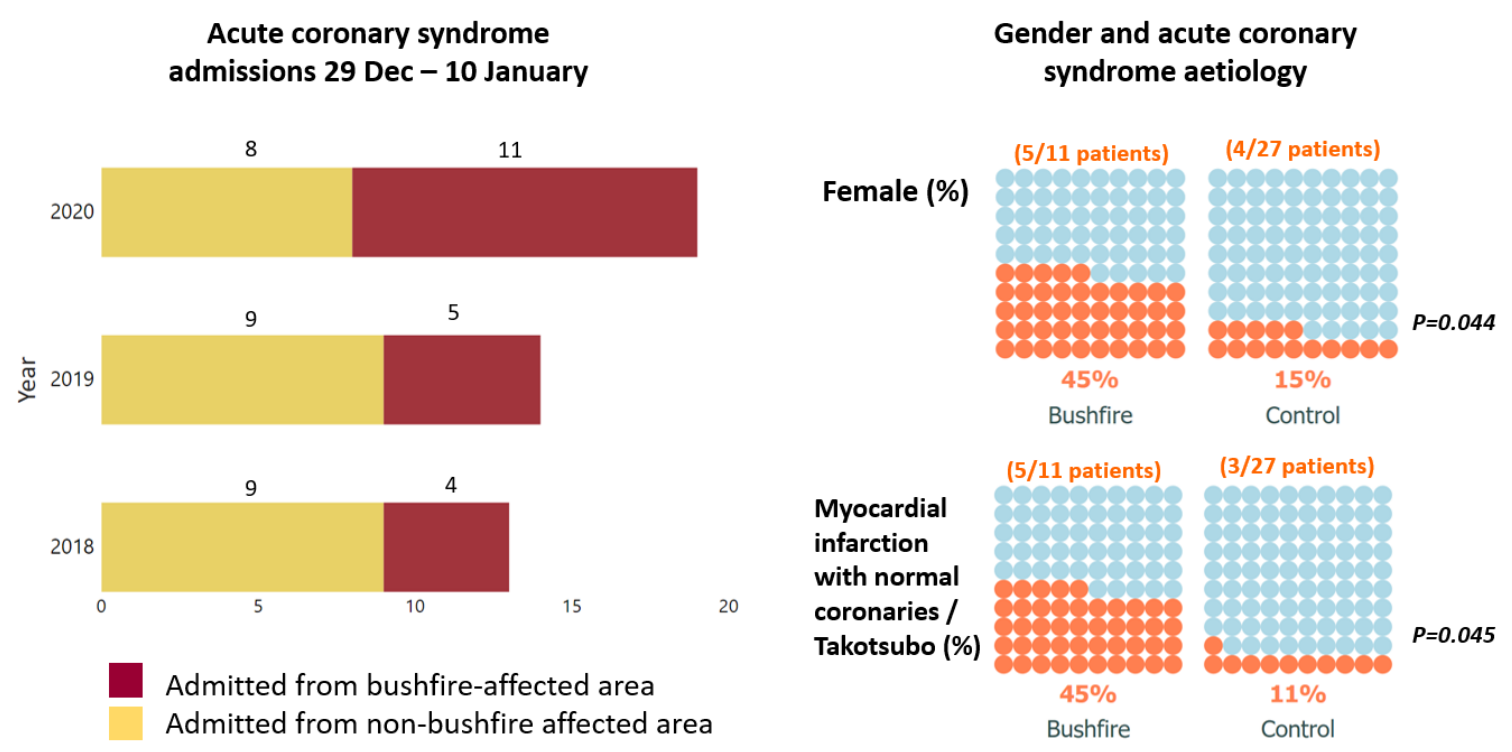

Figure 1. Comparison of patient demographics transferred from bushfire-affected regions with demographics of patients in the preceding two years. Increased volume was observed, and patients from bushfire-affected regions were more likely to be female and receive a diagnosis of MINOCA or Takotsubo as a cause of their ACS presentation. 


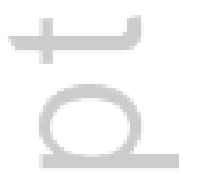

4 
Acute coronary syndrome

admissions 29 Dec - 10 January

8

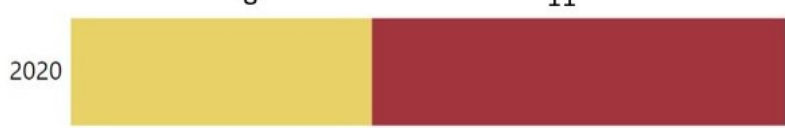

9

5

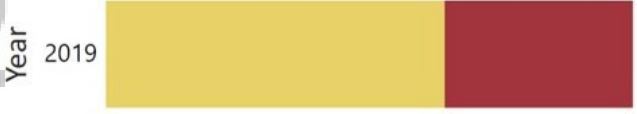

9

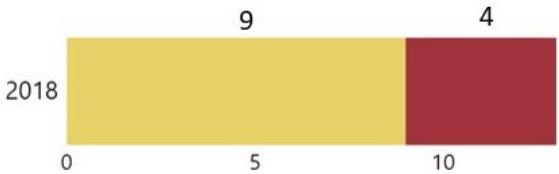

15
Gender and acute coronary syndrome aetiology

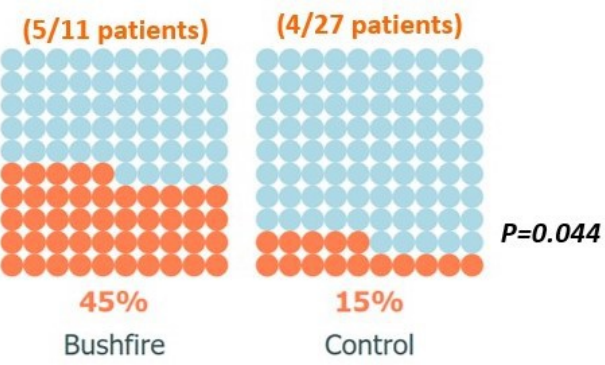

(5/11 patients) $\quad(3 / 27$ patients $)$

Myocardial

infarction

with normal

coronaries /

Takotsubo (\%)
Admitted from bushfire-affected area

Admitted from non-bushfire affected area

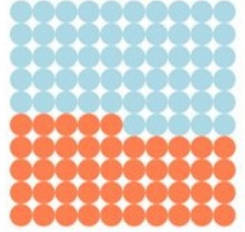

$45 \%$

Bushfire

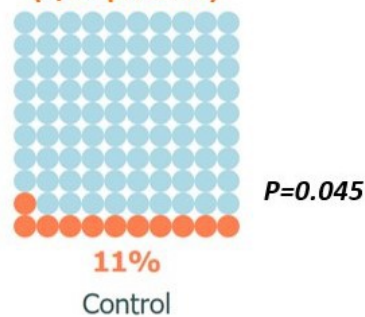

IMJ_15056_Fig 1.jpg

This article is protected by copyright. All rights reserved. 


\title{
Clinical-Scientific Note:
}

\section{Smoke but no fire: increased myocardial infarction with normal coronary arteries in the Australian bushfires?}

\begin{abstract}
Amanda Sherwen Cardiology Registrar MBBS, Elizabeth Paratz Cardiologist MBBS(Hons) FRACP, A/Prof Andre La Gerche Cardiologist MBBS PhD FRACP FCSANZ, A/Prof David Prior Cardiologist MBBS PhD FRACP FCSANZ, A/Prof Andrew Maclsaac Cardiologist MBBS MD FRACP FCSANZ
\end{abstract}

Corresponding Author:

Dr Elizabeth Paratz

Cardiologist, St Vincent's Hospital Melbourne

41 Victoria Parade Fitzroy VIC 3065

eparatz@hotmail.com

Word Count: 495 words

Figures: 1

Keywords: bushfire; environmental medicine; cardiology; acute coronary syndrome 


\section{University Library}

\section{- M M N E R VA A gateway to Melbourne's research publications}

Minerva Access is the Institutional Repository of The University of Melbourne

Author/s:

Sherwen, A;Paratz, E;La Gerche, A;Prior, D;Maclsaac, A

Title:

Smoke but no fire: increased myocardial infarction with normal coronary arteries in the Australian bushfires?

Date:

2020-11-01

Citation:

Sherwen, A., Paratz, E., La Gerche, A., Prior, D. \& Maclsaac, A. (2020). Smoke but no fire: increased myocardial infarction with normal coronary arteries in the Australian bushfires? INTERNAL MEDICINE JOURNAL, 50 (11), pp.1439-+. https://doi.org/10.1111/imj. 15056.

Persistent Link:

http://hdl.handle.net/11343/276558 